\title{
Mantra: Between Habits and Belief of Minangkabau People
}

\author{
Y S Putra ${ }^{1}$, E Meigalia $^{2}$ \\ $\left\{{ }^{1}\right.$ yerri@hum.unand.ac.id, ${ }^{2}$ ekameigalia@hum.unand.ac.id \} \\ ${ }^{1,2}$ Universitas Andalas, Padang, Indonesia
}

\begin{abstract}
This article thoroughly reviews the phenomena of spells in the context of social, Minangkabau culture. The main problem with this mantra phenomenon is how spells can survive in the Minangkabau Muslim community and also how the Minangkabau social and cultural support forms to maintain a habit and belief that deviates from the teachings of their religion, Islam. The habits and needs and demands of Minangkabau customs are factors that have caused spells to survive and are still needed by the Minangkabau people. If it is associated with the process of inheritance, then these factors can indirectly be one model of inheritance of Minangkabau oral traditions to the supporting community.
\end{abstract}

Keywords: Mantra, Minangkabau, Merantau, Islam

\section{INTRODUCTION}

The Minangkabau region is located in the mountainous region of western Central Sumatra. It covers an area of 18,000 square miles which extends from north to south. Navis[1] and Murad[2] mention the Minangkabau cultural area covering the area of luhak and rantau. Luhak is a country of origin consisting of three regions, namely Luhak Tanah Datar, Luhak Agam, and Luhak Limo Puluah Koto, these three regions are known as luhak nan tigo. Whereas the rantau area is luhak nan tigo expansion areas, such as rantau downstream (the area around the Malacca Strait), coastal rantau (areas in the west coast of Sumatra), and land rantau (Solok area, Pasaman, and others). Most of the Minangkabau region is currently found in West Sumatra Province. However, the Mentawai island is not included, because Mentawai is not culturally part of the Minangkabau cultural region. That is why the native inhabitants of West Sumatra (excluding the Mentawai islands) are identical to the Minangkabau people.

The Minangkabau community is well-known as a society that used to live in a heterogeneous environment. This habit makes the Minangkabau people not feel disturbed by the differences and diversity that exists in their environment. Diversity for Minangkabau people is considered as a natural dynamic in human life. This kind of character can be formed because of the mindset of Alam Takambang Jadi Guru, namely a character who highly values social dynamics and change. However, it is this character that makes cultural filtering not work well. The external culture that entered Minangkabau ultimately influenced the system and order of Minangkabau culture. One example of the external influences affecting the Minangkabau culture is Islam. 
In general, Islam entering Minangkabau not only developed religious teachings but also introduced a complete set of rules and culture. Edi Setyawati (2006) in Putra[3] said that the true culture possessed by the Indonesian nation as a result of acculturation with local culture with Islamic culture. He said, that this phenomenon is one of the three great experiences of human civilization in Indonesia, including the Minangkabau.

The acculturation of Islam with the Minangkabau culture finally formed a compromising Minangkabau culture, namely culture that maintains the order of customs and traditions as always. However, it also implements Islamic teachings and functions as a means of legitimacy, both for the legitimacy of political, social and spiritual legitimacy. This consensus is reflected in the traditional philosophy of adat basandi syarak, syarak basandi Kitabullah.

The compromise between adat and religion is very evident in every social life and Minangkabau tradition, even in its literary products. This phenomenon, according to Fang, is inseparable from the effort to glorify Minangkabau culture, which is imaged as a culture that is related to Islamic culture[4]. Zainal Arifin explained that the alignment of the Minangkabau country with two countries (Ruhum / Roma and China) is to create a sense of pride in the Minangkabau generation towards the culture they have. Rome and China are countries with a high civilization[5].

It is possible, the compromising attitude of the unique Minangkabau community has made the Minangkabau tradition and tradition survive until now, as it was sounded in the phrase "no-fade deck, no lap deck" (not cracked/broken/broken due to heat, not weathered because of rain) Minangkabau.

This phenomenon of the Minangkabau compromise with Islam can be found also in the mantra. For this part, the mantra is not only a literary product, but also a cultural product because the mantra was born because of social and cultural support that originated from the habits and beliefs of its people. Therefore, the mantra can be assumed as a social reflection of ancient habits that grow and develop in a society. This habit must ultimately be compromised on developments and social change, in this case, the teachings of Islam. Therefore, this article will cover the forms of social and cultural support for spells so that they can exist and survive in the social environment of the Minangkabau Muslim community.

\section{RESEARCH METHOD}

The method used to review this phenomenon is qualitative. Sugiyono[6] explains that the qualitative method is used to interpret object conditions naturally (as opposed to experiments) with purposive and snowball techniques, triangulation (combined), as well as inductive / quality. Meanwhile, qualitative results emphasize the general explanation of phenomena. In line with this thinking, Moleong[7] defines qualitative as a method that aims to understand a phenomenon in a social context naturally by prioritizing the process of deep communication interactions between researchers and the phenomenon under study. qualitative uses an analytical system called in-depth analysis, which is a system that sees problems from cases. Qualitative methods are also commonly referred to as naturalistic inquiry because this method aims to understand the character, nature and social dynamics that develop at a time, see the world as it is, not the world it should be. This view was expressed by Creswell, in Herdiansyah[8] that "Qualitative research is an inquiry process of understanding based on distinct methodological traditions of inquiry that explores a social or human problem. The researcher builds a complex, a holistic picture, analyzes words, a detailed report on the views of information, and conduct of the study in a natural setting. 
Based on the above understanding, qualitative methods are very appropriate to be used to explain the social phenomena that develop in the Minangkabau community related to the issues mentioned earlier in this paper. The steps taken in the application of qualitative are as follows: First, literature studies, namely collecting library materials, especially those related to spells and social phenomena of the Minangkabau community. Second, make repeated readings of mantra texts and social contexts which are factors for the emergence of social symptoms. Third, interpreting mantra texts and symptoms on a case-by-case basis.

The literature study was carried out on research on mantras reported by Muhadi. In the study, Muhadi collected 25 spells which were classified into the category of immortal spells. He collected the spells from areas such as West Pasaman, Sijunjung, and Pesisir Selatan. In the 25 forms of the immortal mantra, there are 3 types of spells, namely the mantra paga diri, mantra pakasiah, trade spell[9]. The four types of spells incorporated in the category of baka bajalan spells have their respective functions, namely the mantra paga diri serves to protect itself from acts of crime which endanger the physicality of the user of the mantra, the pakasiah spell serves to foster the affection of others to the spell user, Badagang spells serve to increase merchandise trading, and pitunduak spells serve to influence and subdue the other person in order to be willing to accept the spell user's opinions and sayings.

For the needs of this article, 3 of spells will be chosen randomly as a sample of 25 spells that have been collected by Muhadi. The 3 types of spells used as samples in this article are considered to be able to represent each type of mantra included in the category of immortal spells. Among others:

\section{(1). Mantra Paga Diri;}

\section{1]. Bismillahirrahmannirrahim}

1.2]. Tuhan manahan sangko manyangka

\section{3]. Nan basi dalam basi}

\section{4]. Aku mendoakan dindiang pakaian aku di ateh dunia}

1.5]. Antu, palasik, manusia, galang-galang

1.6]. Jikok engkau baniaek salah kapado aku

\section{7]. Engkau kanai sumpah setia}

1.8]. Kanai sumpah kuran $30 \mathrm{juz}$

1.9]. Kanai dek ayaik 15

1.10]. Ka ateh tak buliah bapucuak

1.11]. Ka bawah tak buliah baurek

1.12]. Di tangah digiriak kambang

1.13]. Ka ilia kanai katuak sutan

1.14]. Ka mudiak kanai katual rajo

1.15]. Sabanyak bari di ateh

1.16]. Sabanyak titiak di bawah 
1.17]. Aku duduak dalam kulimah lailahaillallah[9]

(2). Mantra Pakasiah;

2.1]. Bismillahirrahmannirrahim

2.2]. Aie arok aie kursi

2.3]. Nan katigo aie nan janiah tampek basuci

2.4]. Kariang minyak dalam diri batang tubuah si anu

2.5]. Mako kan kariang kasiah sayang si anu kepado aku

2.6]. Jikalau tidak kariang minyak dalam diri batang tubuah si anu

2.7]. Tidak kan kariang kasiah sayang si anu kepado aku

2.8]. Bacarai Allah jo Muhammad

2.9]. Mangko nan pupuih kasiah sayang si anu kapado aku

2.10]. Jikalau tidak bacarai Allah jo Muhammad

2.11]. Tidak kan kariang kasiah sayang si anu kepado aku

2.12]. Barakat laillahaillallah[9]

(3). Mantra Badagang;

3.1]. Bismillahirrahmannirrahim

3.2]. Aku mamakai doa palarih

3.3]. Doa ku cinto mani

3.4]. Bayan Allah hai bayan Allah

3.5]. Karano aku

3.6]. Anak si dang manusia bakasiah sayang kapado aku

3.7]. Aku buruak jadikan elok

3.8]. Aku tuo jadikan mudo

3.9]. Aku miskin jadikan kayo

3.10]. Barakat subhanalloh

3.11]. Hai Allah hai Muhammad

3.12]. Tabikkanlah cahayo

3.14]. Saparti cahayo mani-manikam

3.15]. Panuahkanlah cahayo ku

3.16]. Barangku cinto bagulia kapado Allah 


\subsection{7]. Barokat laillahaillallah[9]}

\section{RESULT AND DISCUSSION}

Mantra is classified into old literature in the form of poetry with mystical content used for certain purposes. Humans believe that behind the life of reality in the world, there is a magical life that cannot be seen but can be felt by its existence. One way to be able to communicate and utilize the power of supernatural beings who live in the magical world is to recite a mantra. Mulyanto explained that the mantra is closely related to human religious attitudes as its users[10].

Mantra can also be said as a set of irregular words but has power for its users. The power of the mantra lies outside the limits of reason and human logic, therefore, it is necessary to have confidence in the wearer so that the spell can work according to the wishes of the reader. It is this belief factor that determines whether the spell will function or not.

Miracle and the efficacy of a mantra will determine how humans treat it. If magic, then not a few people will sacralize it, and treat it excessively. Most of them keep the spells from being exposed to the taboos that the dukun says. This is only to maintain the magic and efficacy of the mantra.

In treating spells, Mulyanto added that usually spells are often not allowed to be spoken by anyone, anytime and anywhere. The pronunciation of the mantra must also be accompanied by a ritual ceremony with an atmosphere that is made in such a way that it has a magical nuance. By treating it like this, many people believe the mantra will emit its magical powers[10].

Usually, spells are present in every oral tradition event, shamanic practices or also local traditional medicine, such as the batatah tradition in Nagari Lubuak Layang, Rao Selatan, Pasaman[11], practice of traditional chicken medicine, dental treatment practices[12], the practice of bakumpang [13] and so on. It can be said that the presence of the mantra in the adat practices indirectly raised the image of the mantra as an important part of an oral tradition. Thus, the community feels the sacredness and religiousness of the practices carried out.

In Minangkabau culture, the mantra has become a mandatory guide for every Minangkabau man who will go abroad. The mantras in the tradition of merantau do not require special rituals in their use, but enough with the capital of conviction and fluent in saying it, the mantra is believed to work according to the wishes of the spell user. This mantra in wanderers is categorized by the term mantra baka bajalan. The term baka bajalan means "provisions for traveling". In the context of sociolinguistics, the word provision refers to something mandatory or a must for someone who is going to travel, be it going to another country or going to the battlefield. Provisions can take the form of tangible objects, such as food, drinks, clothing, weapons, etc., and can also take the form of something intangible such as mentality, courage, knowledge, expertise, including spells.

Going around is a habit that has been carried out by Minangkabau people for a long time. De Jong[14] mentions this migratory habit had grown around the 16th or 17th century and perhaps also in the early 15th century. This habit grew because of the demands in the Minangkabau adat which were matriarchal. The matrilineal system is one system that can survive and work in harmony with the patriarchal Islamic legal framework. Kato[15], Azra[16], and Stark[17] explained that in the matrilineal system, the role and position of women are higher than that of men at every level of kinship, saparuik, sapayuang, and sasuku. At the saparuik family level, namely the level of biological kinship, women are permanent 
residents of the rumah gadang, while men are considered only as immigrants, who do not have a fixed place there.

When married, a man does not have the rights to his children, his position as a husband is not considered to be stingy, as implied in the expression urang sumando bak langau di ikua kabau (urang sumando like a fly in a buffalo tail). This expression means that a husband only lives (lives) in the wife's house. If anything happens, for example, the husband is sent home by his wife's family to his mother's house to be cared for by his saparuik family. If he dies, the husband's body will be buried at his mother's pulmonary cemetery[18].

Surau[16] is a palace for Minangkabau men. Before Islam entered Minangkabau, surau had played its function as a learning media and home for Minangkabau men. In that place, men spend their days doing learning and playing activities. The martial arts of silat and randai are two forms of art that are often taught in surau. So, it is not strange if there are many Minangkabau men are clever and good at clever skills. At night, Minangkabau men settled and rested also at Surau. When Islam entered Minangkabau, the function of the surau did not change. However, religious learning materials are taught more than silat and randai. During the Islamic period, surau became a place of religious learning during the day, and in the evening Minangkabau men could learn randai and silat. Perhaps, because Surau is the center of the development of Islamic teachings and civilization, the religion of Islam can develop rapidly in Minangkabau. In other words, men are the main actors in the development of Islam in the Minangkabau.

A Minangkabau man will not always live in Surau, there is a time they have to leave that place. Due to demands in matrilineal customs, and problems of self-esteem, most Minangkabau men who have grown up will choose to go abroad to leave their homes and hometowns to try their luck in overseas countries. At this time, Minangkabau men will be given provisions by Mamak or Tuanku as a guide for him to go abroad. Muhadi[9] explained that there were 2 types of provisions commonly given to Minangkabau men, namely the provision of birth and provision of the mind. Provision of birth is the expertise they get in surau, namely the science of religion, silat and the arts, while the provision of the mind is a provision that is magical in nature, namely the manto or mantra. There are 3 types of spells given, namely mantra (1), (2), and (3).

This situation can be assumed as the times when Minangkabau people compromise with Islam. Why is that, it is nothing else because in the teachings of Islam the activities that lead to shirk behavior are strictly prohibited because shirk is included in major sin. But, even though they have studied and studied Islam in surau, they still agree that mental provisions must still be given. Lauik sati, rantau batuah, urang di dunie banyak kiramaik (meaning that in this world not everyone will behave well, there must be someone who will harm and make destruction) thus the Minangkabau people see the vast world.

In terms of the form of a spell, this compromise can be seen from the form of the spell given. Mak Ujang, one of the informants chosen by Muhadi in his research said that the manto or mantra in Minangkabau can be divided into 2 categories, the first category of old spells, namely mantra which is still mediated by animistic beliefs that are considered shirk, the second category is a new mantra, namely mantra who have adapted to Islam. This 2nd category of spells is given as a provision for Minangkabau men who will go abroad.

The characteristics of spells that have adapted to the Islamic religion, namely,

The first is the use of the word "bismillahirrahmanirrahim" as the opening word and closed by saying "Barakat laillahaillallah" (meaning the one blessing of Allah), This can be seen in each of the spells above, (1), (2), and (3). Zuhdi[19] explains that the word bismillahirrahmannirrahim is hope and prayer to a loving and most merciful God. If this word 
is pronounced violently it will open the eyes of the heart and calmness for that person. This calm soul and broad heart indirectly add to the strength of the person who reads it. The word bismillahirrahmannirrahim also indicates that there is a request to Allah SWT, to give strength and ability to the person who speaks it. In other words, this is an attempt to avoid the treatment of shirk in the use of spells. Mantra is always closed by reciting the barakat laillahaillallah. The sentence barakat laillahaillallah means God's one blessing. This indicates that if the desired power is indeed given to the user of the mantra, then all of that is a gift from Allah SWT, not another subtle creature, as some people believe.

The second characteristic is the belief that disasters and calamities come from Allah SWT, such as those found in mantra (1) lines 1.8] and 1.9]:

\section{8]. Kanai sumpah kuran $30 \mathrm{juz}$}

Kuran means Al Quran, a representation of the language and instructions of Allah SWT. If the language and instructions of Allah are ignored, then Allah will give a worthy reply to those who ignore God's instructions.

\section{9]. Kanai dek ayaik 15}

Ayaik 15, in the belief of Muslims, is a collection of verses that give kindness to people who are often read and obeyed. The benefits obtained from paragraph 15 include: Obtaining forgiveness of sins, being rushed to sustenance, being loved by everyone, being able to protect others, avoiding danger, being able to cripple those who will do evil, given a way out of all the difficulties that confront. Imagine the consequences if condemned by verse 15 , then what is obtained is the opposite of the good in verse 15 .

The third characteristic is that the desired love is like the love of Allah SWT to the Prophet Muhammad. Like the text in spells (2) lines:

\section{8]. Bacarai Allah jo Muhammad}

\section{9]. Mangko nan pupuih kasiah sayang si anu kapado aku}

\subsection{0]. Jikalau tidak bacarai Allah jo Muhammad}

\subsection{Tidak kan kariang kasiah sayang si anu kepado aku}

Line 2.8]; 2.9]; 2.10]; and 2.11] in mantra (2) is a paradoxical situation. This is because that is the belief of Muslims, Allah SWT loved the Prophet, Muhammad. The love of Allah SWT to the Prophet Muhammad was shown when giving salawat and greetings to the Prophet Muhammad and ordering all angels to pray to the Prophet Muhammad (Surah Al Ahzab-56). In other words, line 2.8]; 2.9], and 2.11] in mantra (2) in essence is a form of a request that cannot be rejected if Allah SWT wants it.

The fourth characteristic is the loss of magical or supernatural or supernatural nuances in each line in mantra (1), (2), (3). Typically a mantra, diction derived from the names of astral beings such as kuntilanak, nyai, inyiak and others believed to be sources of strength have not been found in spells of mischief. 


\section{CONCLUSIONS}

The Minangkabau compromise attitude towards Islam has transformed the unfaithful mantras into spells that are following the teachings of Islam and far from the elements of syirik. In other words, the oblique view of people who are against Minangkabau people who still maintain an animistic habit indirectly has been refuted, because it turns out, in spite of that, the mystical elements have been lost. Although it still retains its spell form, its nature is nothing more than a prayer to Allah SWT.

\section{REFERENCES}

[1] A. Navis, Alam Terkambang Jadi Guru. Jakarta: Grafiti Press, 1984.

[2] A. Murad, "Merantau: Aspek of Out Migration of The Minangkabau People," Australian National University, 1978.

[3] Y. S. Putra, "Humanisme Teosentris dalam Sastra Islam Minangkabau: Kajian Atas Nazam-nazam Minangkabau,” no. 2009. Gadjah Mada University, Yogyakarta, hal. 125,2014

[4] Y. Fang, Sejarah Kesusastraan Melayu Klasik, Indonesia. Singapura: Pustaka Nasional PTE LTD, 1982.

[5] Z. Arifin, "Dualitas dalam masyarakat Minangkabau: Studi kasus praktik perkawinan di dua nagari." Gadjah Mada University, Yogyakarta, hal. 613, 2009.

[6] P. D. Sugiyono, Metode Penelitian Kuantitatif, Kualitatif dan R\&D, 28 ed. Bandung: Alfabeta, 2018.

[7] L. J. Moleong, Qualitative Research: Metode Penelitian, Analisis Data, Wawancara. Bandung: Remaja Rosdakarya, 2000.

[8] H. Herdiansyah, Metodologi Penelitian Kualitatif Untuk Ilmu-Ilmu Sosial. Jakarta: Salemba Humanika, 2010.

[9] R. Muhadi, "Mantra Baka Bajalan dalam Tradisi Merantau Orang Minangkabau," no. Thesis. Andalas University, Padang, hal. 30, 59, 65, 88, 2019.

[10] Mulyanto dan E. Suwanto, "Bentuk dan Fungsi Mantra," J. Kadera Bhs., vol. 9, no. 2, hal. 75-87, 2017.

[11] E. Gani, "Mantra Batatah di Nagari Lubuk Layang Kecamatan Rao Selatan Kabupaten Pasaman," Pendidik. Bhs. dan Sastra Indones., vol. 1, no. 2, hal. 1-7, 2013.

[12] S. E. Iswadi Bahardur, "Unsur-Unsur Ekologi Dalam Sastra Lisan Mantra Pengobatan Sakit Gigi Di Kelurahan Kuranji," Basindo J. Kaji. Bahasa, Sastra Indones. dan Pembelajarannya, vol. 1, no. 2, hal. 24-30, 2017.

[13] Y. Wardani, T. Priyadi, dan H. Sanulita, "Struktur Dan Makna Mantra Bekumpang Sastra Lisan Dayak Kantuk,” J. Pendidik. dan Pembelajaran, vol. 4, no. 1, hal. 1-11, 2015.

[14] P. E. D. J. De Jong, Minangkabau and Negeri Sembilan: Socio-Political Structure In Indonesia. Den Haag: Martinus Nijhoof Uitgeverij, 1980.

[15] T. Kato, Adat Minangkabau dan Merantau dalam Perspektif Sejarah. Jakarta: Balai Pustaka, 2005.

[16] A. Azra, Surau: Pendidikan Islam Tradisional dalam Transisi dan Modernisasi, Indonesia. Jakarta: Logos Wacana Ilmu dan Pendidikan, 2003.

[17] A. Stark, "The Matrilineal System of the Minangkabau and its Persistence Throughout History: A Structural Perspective," Southeast Asia A Multidiscip. J., vol. 13, no. January 2013, hal. 1-13, 2013. 
[18] M. D. Nasroen, Dasar Falsafah Adat Minangkabau. Jakarta: Pasaman, 1971.

[19] M. S. Drs. B Muria Zuhdi, "BASMALAH (Karya Kriya Kayu)." hal. 1-11, 2012.

[20] B.W. Setyawan and K. Saddhono, "Eret traditional ceremony as representation of spirit of mutual cooperation among coastal communities". Adv. Sci. Let. vol. 23 no.10, pp 9991-9992, 2017 